\title{
PRODUCTION AND MARKET OF ECOLOGICAL PRODUCT IN POLAND
}

Ewa KORELESKA, Faculty of Management, UTP University of Science and Technology in Bydgoszcz, ul. Fordońska 430, 85-790 Bydgoszcz, Poland, ewa.koreleska@utp.edu.pl

\begin{abstract}
The goal of this study is to evaluate the condition and development prospects of ecological farming and its product market in Poland. Sources of data used for the analysis included: IJHARS (Agicultural and Food Quality Inspection) national reports, literature, and information provided by experts and consumers. The time frame of the research covers the years 2004-2020. The date of Poland's accession to the EU 2004, and subsequent formal-legal factors were taken into consideration to schedule the time frame of the research. The trend was analyzed in reference to the number of ecological farms and the area of ecological farmlands as well as ecological manufacturers in 2004-2016. The method of the "least squares" was used in the study. Parameters of the trend function equation (linear, square) were determined by means of this method. MS Excel calculation sheet was used as a calculation tool. The value of determination coefficients indicated good consistence of the determined trend lines with empirical data. A distinctive linear trend with upward tendency in the number of ecological manufacturers was found in the analysed period of time. According to the determined trend function, the number of ecological manufacturers could be more than 764 in 2020, that is, reach the expected value according to the assumptions of the Framework Action Plan for Ecological Agriculture and Food in Poland for the years 2014-2020. The analyses were confronted with the experts' assessment results carried out by the method of online survey and consumers" assessment by the method of group interview carried out in 2017. Two measurement instruments were prepared, that is, a survey questionnaire and interview scenario. It needs to be noted that although during the last 3 years a drop in eco-production was reported, development of ecological agriculture and its product market in Poland is possible, on condition that the government policy in this field is consistent and predictable, the society becomes richer and the ecological awareness of both farmers and consumers improves.
\end{abstract}

Keywords: organic agriculture, organic food, ecological food, organic market, organic marketing, development, trend function, evolution trend

\section{INTRODUCTION}

Ecological farming is inseparabely connected with the concept of sustainable development which is one of the priorities of the European Union. More and more scientific publications are dedicated to this economic system and market of its products (Matyjaszczyk and Szulc, 2016; Prus, 2008; Śmiechowska and Florek ,2011; Żakowska-Biemans, 2011). Some of them deal with analyses of development tendencies of this kind of production (Pondel ,2016; Runowski, 2009). These analyses can be a source of information for farmers and agricultural advisors who are important links in the knowledge-based information system used by both farmers (Prus and Drzazdzynska, 2017) and entrepreneurs, facilitating their decision-making and limiting the risk of their business. The studies can also provide help in shaping the state policy for this sector of economy.

\section{Goal, material and the research method}

The goal of this study is to evaluate the condition and development prospects of ecological farming and its product market in Poland. Sources of data used for the analysis included: IJHARS (Agricultural and Food Quality Inspection) national reports, literature, and information provided by experts and consumers. The time frame of the research covers the years 2004-2020. The date of Poland's accession to the EU 2004, and subsequent formal-legal factors were taken into consideration to schedule the time frame of the research. The trend was analyzed in reference to the number of ecological farms and the area of ecological farmlands as well as ecological manufacturers in 2004-2016. The method of the least squares was used in the study. Parameters of the trend function equation (linear, square) were determined by means of this method. MS Excel calculation sheet was used as a calculation tool. The value of determination coefficients indicated good consistence of the determined trend lines with empirical data. The analyses were confronted with the experts' assessment results carried out by the method of online survey and consumers" assessment by the method of group interview carried out in 2017. The survey of consumers included interviewing three groups of ten respondents. The group of experts included both researchers and practitioners. Totally, this group consisted of fifty persons. Two measurement instruments were prepared, that is, a survey questionnaire and interview scenario. The obtained data and carried out analyses allowed to formulate the conclusions included in the final part of the study.

Copyright (C) 2017 The Authors. Published by Aleksandras Stulginskis University. This is an open-access article distributed under the terms of the Creative Commons Attribution License (CC-BY 4.0), which permits unrestricted use, distribution, and reproduction in any medium, provided the original author and source are credited. 


\section{RESEARCH RESULTS AND DISCUSSION}

Recently, the ecological branch in Poland has been constantly increasing. In 2004-2014 the number of ecological farms and the area of farmlands as well as the number of manufacturers involved in the ecological branch was found to be constantly rising (fig.1,2,3). However, since 2014 a drop in the number of ecological farms and the area of ecological farmlands has been reported, with a further increase in the number of ecological manufacturers. The trend function shows that in the analyzed period of time, 2004-2016, the number of manufacturers increased anually by nearly 45.15 of units, and in 2020 the number of manufacturers can be 764.974, that is, it will exceed the level of 700 assumed in the Framework Plan for Food and Ecological Agriculture for 2014-2020. Experts relate the observed drop to introduction, on 13 March 2013 by the Minister of Agriculture, a new regulation significantly restricting access to the funds available within the ecological farming packet of the agricultural-environmental program. Subsidies for horticulture were totally stopped for new applicants (moved back to 2015), whereas subsidies for permanent grasslands were reserved for farmers who owned herbivorous animals (cattle, horses, sheep, goats) $-0.5 \mathrm{DJP} / \mathrm{ha} \mathrm{TUZ}$. These changes slowed down the increase in the number of organic farms, in 2013. In result of successive changes in the agricultural-environmental program - packet 2 and new action - Ecological Agriculture in PROW 2014-2020 containing many requirements difficult to meet, farmers finishing a 5 year long ecological commitment do not enter into the next one. Moreover it was found that changes in granting subsidy criteria for ecological production are definitely to frequent, sometimes irrational and cancelled after 2 or 3 years. Owners of ecological farms get lost in the crowd of changing laws and resign from further production in this system". Other experts think that changes in subsiding agriculture are still necessary and those farms that quit ecological methods were not really oriented to provide ecological products but to obtain financial profits. There were experts who indicated other causes of resigning from ecological management system, ie. 'problems with plant and animal material for ecological production', 'regulations on GMO, including problems with GMO free feeder', 'lack of stable market for ecological products', 'high costs of ecological production', 'fears connected with reduction of subsidies for ecological product or abandonment of subsidies'. It was also indicated that 'Some farms resign from certification though they still produce ecological products'.

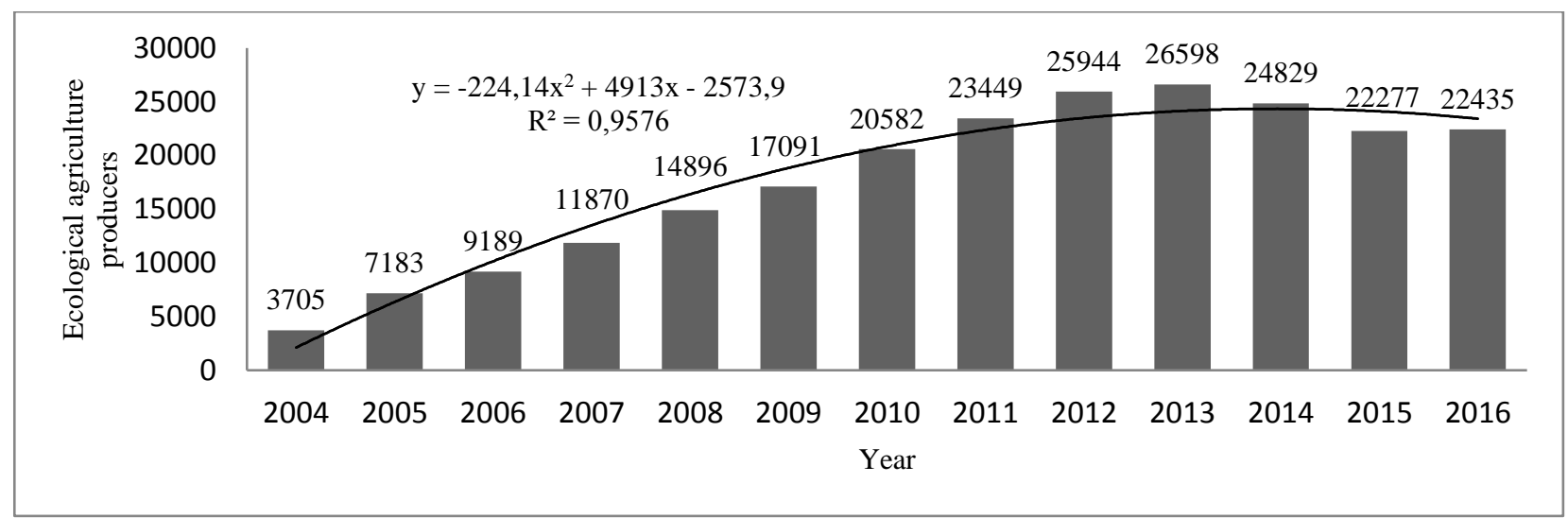

Source: own research on the basis of the report on organic farming in Poland in 2016-2016, IJHARS (Agricultural and Food Quality Inspection), Warsaw 2017

Figure 1. Number of ecological agricultural producers in Poland in 2004-2016

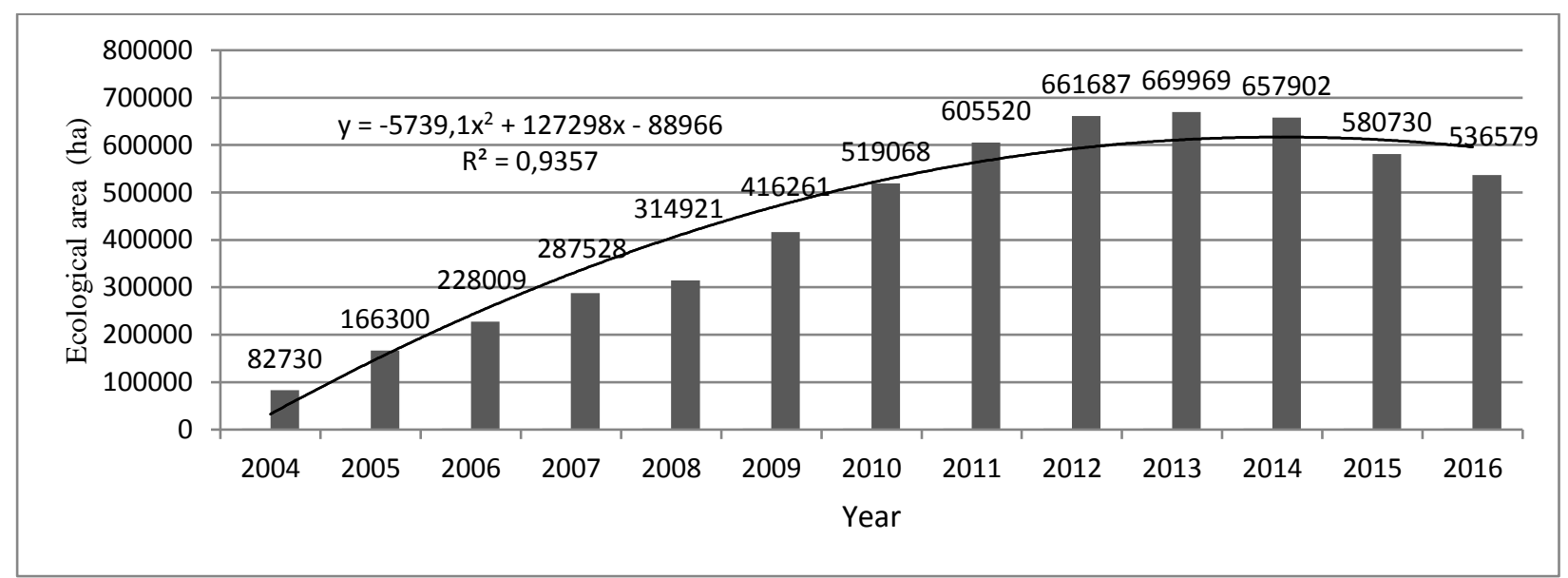

Source: Own research on the basis of the report on organic farming in Poland in 2016-2016, IJHARS (Agricultural and Food Quality Inspection), Warsaw 2017.

Figure 2. Area of ecological farmlands in Poland in 2004-2016 


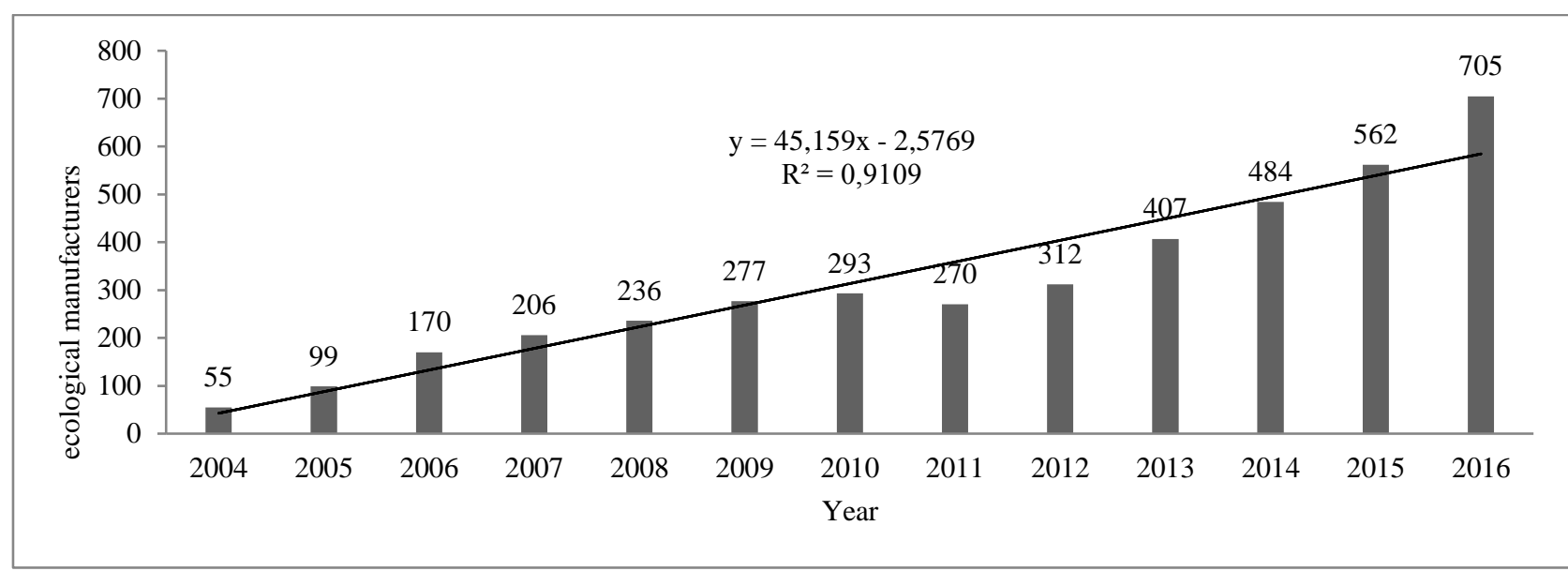

Source: Own research on the basis of the report on organic farming in Poland in 2016-2016, IJHARS (Agricultural and Food Quality Inspection), Warsaw 2017

Figure 3. Number of ecological manufacturers in Poland 2004-2016

Most of experts (70\%) are of the opinion that organic farming in Poland will continue to develop in the next 10-20 years. This is due to the dynamic growth of ecological farming worldwide, especially in the European Union. Currently this sector is the most dynamically developing branch. According to experts, this growth is accelerated by the policy of the state which is reflected by actions directed both to farmers and consumers. Experts report that ecological agriculture in Poland was given support by implementation of Sustainable Development Strategy for rural areas, agriculture and fishing for the years 2012-2020 (SZRWRiR). Nevertheless, more support is expected form the government and the Ministry of Agriculture and Rural Areas Development. This is to be implemented by 'Wise, predictable and reliable policy and promotion of actions to support sustainable management of farmlands in order to protect soil, water, climate precious natural habitats and threatened species of birds as well as genetic resources of plants and farm animals and protection of landscape diversity. 'Financial support by the government is indispensable for this kind of management system'. It is postulated that ' subsidies need to be continued though by introduction of better verification systems and more effective control and appreciation for those whose production is directed to reach the market".

Also the idea of integration and cooperation of ecological farmers need to be supported. The following opinions were reported 'Stimulation of the idea of integration of manufacturers, partnerships among ecological farmers', 'setting groups in order to search for attractive sales markets', 'boosting cooperation between farmers'.

Significance of awareness of both the farmers and consumers was highlighted. Experts are for 'widespread education of the society at different education levels including participation of the Minister of Education, Minister of Science and Higher Education and the Ministry of Health and Social Care in construction of ecological awareness and health supporting attitudes'. This is supposed to cause an increase in the demand for organic products.. Experts name many non-governmental institutions which support ecological actions such as. eg.: Polish Ecological Club, REFA Ecological Movement of Saint Francis from z Assisi, Foundation for Support of Ecological Initiatives, Workshop on behalf of all creatures, Polish Green Network and Foundation - Our Earth. „Operation of these institutions has already contributed and will contribute to raising the level of the society ecological awareness, improving responsibility for the natural environment and undertaking actions for its protection".

Experts $(100 \%)$ indicate that the market of ecological products in Poland is starting to develop and this is due to the growth of GDB and rising ecological awareness of the society. The supply of organic food is still too small and accounts for a small part of marketed food.

The research carried out by TNS Poland show that $4 \%$ of inhabitants regularly purchase organic food and $26 \%$ do it occasionally though they declare willingness to buy it more often.

The most frequently indicated place of ecological products purchase are specialist stores (47\%). $27 \%$ declared buying the products directly from agricultural farms, 22\% - on the market, 16\% - in a supermarket, 3\% - online [Organic Farma, 2012]. The assortment of organic products in points of sales is not sufficient and the products often come from abroad [Koreleska, Chwal 2016].

In Poland there are many brands used for labeling ecological food. The oldest is the trade mark used for the Association of Ecological Food Producers Ekoland (Fig. 4). Knowledge of the European Union trade mark to label organic food in Poland is rising. According to the survey carried out for a representative group of Poles in 2014 familiarity with the trade mark was declared by $39 \%$ of respondents. Earlier surveys indicated 27\% (2012) and 21\% (2013). (Investigation of awareness ...2013, 2014).

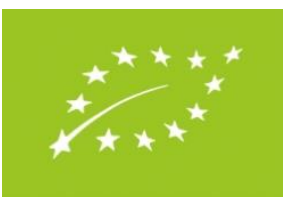

A

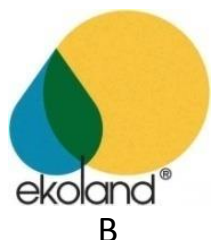

B

Source : http://ekoexpo.pl/pl/zywnosc_ekologiczna, http://www.ekolandzach.pl/index.php?news\&nid=62

Figure 4. Union trade mark for organic food (A) and trade mark for the Association of Ecological Food Producers (B) 
Experts indicate that the ecological food market is not developing as fast as food manufactures would expect. In their opinion this is caused by many different factors, first of all by high organizational and logistic costs connected with implementation of systems to produce organic food products, poor marketing and advertising of ecological products. Some experts think that ecological food production will continue to develop, though..."it is still a long way to go to reach some kind of domination'.

According to experts, growth of the organic market largely depends on wealthiness and ecological awareness of the Polish society. The following statements were reported during the survey: only the income rise and ecological awareness', ímproving distinctiveness of labeling and knowledge of benefits the products provide', 'people need to be educated form the kindergarten', 'increase in the society wealthiness and promotion of a healthy lifestyle'. It was also indicated that price reduction of organic products could contribute to the development of the organic food market.

It was also indicated that reduction of the organic product prices could contribute to the development of ecological food market. Like in the case of the factors boosting the development of ecological farming also the importance of consumers' integration was indicated, focusing on creation of cooperatives. According to experts, it is also the support of local authorities in the form of: organization of fairs, stalls and local eco food promotion events that matters.

However, the opinions of Polish consumers on the subject of eco food production and market development were more divided. Part of them were of the opinion that this is only a short lasting trend' which will pass sooner or later, 'the prices of ecological products are too high and farmers will not turn to organic food production system in fear of drop in crops. Resistance on the side of equipment producers for conventional farming was indicated as well. Other respondents were of the opinion that development of the ecological farming is inevitable as people reach for good quality food more often and this tendency is to be continued. According to researchers, further development of ecological farming would also be accelerated if there was more support from the government. Additionally, introduction of legal regulations are needed to facilitate direct sale of farmers' own products.

\section{CONCLUSIONS}

1. Development of the ecological branch was reported in Poland in 2004-2017. A linear trend in foundation of ecological processing plants with distinct upward tendency was observed in this period. As the determined trend function shows, the number of ecological food processing plants could reach in 2020, the number of over 764, that is, reach the value assumed in the Framework Plan for Ecological Food and Agriculture for 2014-2020. It needs to be noted that a too small number of ecological manufacturers as compared to the number of ecological farms in Poland is, among others, due to sale of organic products as conventional ones, hence changes need to be introduced and the trend observed for the analyzed period is positive.

2. It needs to be noted that although during the last 3 years a drop in eco-production was reported, development of ecological agriculture and its product market in Poland is possible, on condition that the government policy in this field is consistent and predictable, the society becomes richer and the ecological awareness of both farmers and consumers improves.

3. Both experts and consumers indicate the necessity of integration and cooperation among ecological farmers and consumers of organic food as an important factor to boost the development of ecological agriculture on Poland. Also the Organic Food and Agricultural Plan in Poland for 2014-2020 indicates insufficient level of farmers' integration and little interest in cooperation. The Ministry should introduce financial incentives to support cooperation between farmers, create formal groups and take actions to provide information on the subject. This can encourage farmers to integrate which in turn can have a positive influence on information, implementation of innovation, experience exchange, strengthening the position of small producers in the supply chain and provide the possibility to use external financial sources.

4. According to the consumers, development of ecological agriculture and its product market will be conditioned by the lifestyle of consumers and financial support for the ecological branch from the government.

\section{REFERENCES}

1. Assessment of ecological awareness and behavior of Polish citizens - October 2014 TNS Poland for the Ministry of The Environment TSN November p.69.

2. Assessment of ecological awareness of Polish citizens - tracking tests - October 2013, Report PBS prepared for the Ministry of the Environment Sopot, 28 October 2013, p.107.

3. Framework Plan for Ecological Food and Agriculture in Poland for 2014-2020 the Ministry of Agriculture and Rural areas Development. Available at http://C:/Documents\%20and\%20Settings/xp/Moje\%20dokumenty/Downloads/Ramowy\%20Plan\%20Dzialan\%202014-2020\%201\%20sierpnia\%202014\%20(2).pdf (Accessed on 10/11/2017)

4. Koreleska ,E., Chwal, K. 2016. Assessment of availability of organic food in selected sale points in Bydgoszcz. Annals of Scientific SERIA, XVIII, 2016, Vol. 5, pp. 87-91.

5. Matyjaszczyk, E., Szulc, M. 2016. Protection possibilities of organic crops against insect pests in the European Union. Journal of Research and Applications in Agricultural Engineering, Vol. 61(4), pp. 47-51. [In Polish].

6. Organic Health Farm 2013 unit. Report for 2012 [W] Kwasek M. (ed.). From research on socially sustainable farming (21) ecological food-legal regulations -system of control and certification ERiGŻ, Warszawa 2013 
7. Pondel, H. 2016. Evolution Trends in organic food produkction in Poland. Journal of Research and Applications in Agricultural Engineering, 2016, Vol. 61(4), pp. 132-135. [In Polish].

8. Prus, P. 2008. Sustainable development of individual farms based on chosen groups of farmers. EJPAU 11(3), \#06. Available at http://www.ejpau.media.pl/volume11/issue3/art-06.html (Accessed on 10/11/2017)

9. Prus, P., Drzazdzynska, K. 2017. Farmers' Assessment of Training Services and the Impact of Agricultural Advisory on Selected Developmental Factors Affecting Farming. Proceedings of the 2017 International Conference "Economic Science for Rural Development", No 44, pp. 338-344, Latvia University of Agriculture.

10. Runowski H. 2009. Organic farming progress or regress? Annals of scientific Annals of Agricultural Sciences, Series G, Vol. 96 , No. 4, pp. 152-156.

11. Śmiechowska M., Florek A. 2011. Content of heavy metals in selected vegetables from conventional, organic and allotment cultivation. Journal of Research and Applications in Agricultural Engineering, Vol 46(4), pp. 132-135. [In Polish].

12. The report on organic farming in Poland in 2016-2016, IJHARS. Agricultural and Food Quality Inspection, Warszawa 2017.

13. Żakowska-Biemans S. 2011. Barriers to buy organic food in the context of organic food market development. Journal of Research and Applications in Agricultural Engineering, Vol. 46(4), pp. 216-220. [In Polish]. 